\title{
ANALISIS LIKUIDITAS DAN PROFITABILITAS HUBUNGANNYA DENGAN ASSET LIABILITY MANAGEMENT
}

\author{
Isnanda Nurillah ${ }^{1}$, Dwi Listyowati ${ }^{2}$ \\ Sekolah Tinggi IImu Ekonomi Jayakarta \\ isnandanurillah@gmail.com ${ }^{1}$, dwilistyowati6@gmail.com²
}

\begin{abstract}
A B S T R A K
Penelitian ini bertujuan untuk menganalisis laporan keuangan dalam mengelolakan asset perusahaan pada Likuiditas dan Profitabilitas Hubungannya Dengan Asset Liability Management. Variabel bebasnya adalah Likuiditas dan Profitabilitas sedangkan variabel terikat adalah Asset liability Management. Objek yang digunakan adalah PT Pelita Air Service. Jenis penelitian yang digunakan adalah penelitian kepustakaan. Sedangkan teknik pengumpulan data yang digunakan adalah dengan pengutipan dokumen yang ada pada PT Pelita Air Service. Teknik analisis data yang digunakan adalah analisis data kualitatif yaitu menggunakan penjabaran melalui kalimat-kalimat dan analisis data kuantitaf yaitu melalui perhitungan rasio likuiditas dan rasio profitabilitas. Simpulan dari hasil analisis selama tiga tahun dengan indikator rasio lancar berfluktuasi untuk yang disebabkan oleh adanya peningkatan aset lancar dengan current tersebut kewajiban. Sedangkan analisis rasio profitabilitas dengan menggunakan Net profit margin, aset Balik, return on investment, dan kembali pada pengalaman ekuitas degradasi disebabkan oleh manajemen perusahaan yang masih kurang efisien dalam melakukan biaya operasi per tahun. Dengan demikian sebaiknya jika perusahaan tetap menjaga dan meningkatkan kembali profitabilitas perusahaan dengan tetap melakukan efisiensi biaya dari sisi operasional dan biaya-biaya yang dianggap tidak perlu.
\end{abstract}

KataKunci: Likuiditas, Profitabilitas, dan Asset Liability Management.

\section{PENDAHULUAN}

Pada umumnya suatu perusahaan mempunyai sasaran tertentu yang ingin dicapai, yaitu mendapatkan laba atau keuntungan, maka diperlukan kerjasama yang teratur dan terintregrasi antara fungsi-fungsi dalam perusahaan. Salah satu aspek yang perlu diperhatikan bagi sebuah perusahaan adalah bagaimana mengelola kebijakan keuntungan dengan baik. Oleh karena itu pihak manajemen perusahaan menyusun laporan

$\begin{array}{lr}\begin{array}{l}\text { keuangan untuk } \\ \text { menggambarkan }\end{array} & \begin{array}{r}\text { dapat } \\ \text { kegiatan } \\ \text { perusahaan selama } \\ \text { periode }\end{array} \\ \begin{array}{l}\text { tertentu. } \\ \text { Untuk }\end{array} & \begin{array}{r}\text { menjaga } \\ \text { suatu }\end{array} \\ \begin{array}{l}\text { kelangsungan hidup } \\ \text { perusahaan }\end{array} & \text { harus } \\ \text { mempertimbangkan aspek } \\ \text { likuiditas dan profitabilitas. Ini } \\ \text { merupakan dua hal yang sangat } \\ \text { penting terhadap perkembangan } \\ \text { asset liability di dalam suatu } \\ \text { perusahaan. Adapun likuiditas } \\ \text { perusahaan } \begin{array}{r}\text { menyangkut } \\ \text { kemampuan perusahaan dalam }\end{array}\end{array}$


Jurnal Manajemen dan Bisnis Jayakarta, Volume 1, No. 2, Januari 2020

melunasi kewajiban jangka pendeknya pada saat jatuh tempo. Sedangkan profitabilitas perusahaan menyangkut kemampuan perusahaan menghasilkan laba atau keuntungan. Jumlah alat-alat pembayaran (alat-alat likuid) yang dimiliki oleh suatu perusahaan pada saat tertentu merupakan "kekuatan membayar" dari perusahaan yang bersangkutan. Suatu perusahaan yang mempunyai "kekuatan pembayaran" belum tentu dapat memenuhi segala kewajiban finansialnya yang harus segera dipenuhi atau dengan kata lain, perusahaan tersebut belum tentu mempunyai "kemampuan membayar".

"Kemampuan membayar" terdapat pada perusahaan apabila "kekuatan membayarnya adalah demikian besarnya sehingga dapat memenuhi semua kewajiaban finansial yang segera harus dipenuhi. Dengan demikian maka kemampuan membayar itu baru dapat diketahui setelah dibandingkan "kekuatan membayarnya di satu pihak dengan kewajibankewajiban finansial yang harus segera dipenuhi dengan pihak lain.

Namun sering terjadi bahwa perusahaan tidak mampu menyelaraskan hal tersebut karena suatu posisi likuiditas tidak memadai akibat orientasi perusahaan yang selalu mengejar keuntungan tanpa mengimbangi pengelolaan aspek likuiditas atau karena perusahaan terlalu memperhatikan likuiditas sehingga melalaikan aspek profitabilitasnya terhadap asset liability management perusahaan.

Perusahaan didirikan dengan tujuan antara lain untuk mendapatkan meningkatkan kinerja, maksimisasi nilai perusahaan. Dengan nilai perusahaan yang tinggi akan dapat meningkatkan jumlah kekayaan para pemilik modal sendiri. Oleh karena itu, dalam teori manajemen keuangan disebutkan bahwa tujuan perusahaan adalah untuk mengelola aliran dana tersebut sesuai dengan tujuan yang telah ditetapkan sebelumnya.

Diartikan manajemen keuangan di dalam kinerjanya dibantu oleh seorang manajer keuangan, yang bertanggung jawab atas pengambilan keputusan penting mengenai investasi (investment) dan pendanaan (financing). Manajer keuangan akan terlibat langsung dalam perencanaan dan pengendalian penggunaan dana, perolehan dana yang sesuai dengan kebutuhannya, jangka waktu, persyaratan maupun biayanya. Dana akan diperoleh baik dari pasar modal maupun dari bank ataupun dari sumbersumber dana lainnya. Dengan demikian manajer keuangan sangat berperan dalam melancarkan aliran kas dana dari luar atau ke dalam perusahaan, ataupun sebaliknya dari dalam ke luar perusahaan, yaitu pembayaran kepada pemilik perusahaan dan pembayaran kembali utang kepada para kreditur. 
Jurnal Manajemen dan Bisnis Jayakarta, Volume 1, No. 2, Januari 2020

\section{Dengan}

cara

penghimpunan dana masyarakat dengan tujuan berorientasi laba (Profit Oriented). Namun laba yang dimaksudkan adalah hasil dari selisih antara pendapatan atas penanaman dana dan biayabiaya yang dikeluarkan selama periode tertentu. Untuk mendapatkan suatu aturan keputusan yang secara operasional konsisten dengan tujuan perusahaan, perlu dipertimbangkan dua kondisi analisis rasio keuangan yang menghubungankan asset liability management perusahaan, yaitu rasio likuiditas dan rasio profitabilitas, yang dapat dilihat dari menganalisis posisi neraca dan laporan laba rugi perusahaan tersebut.

Laba yang ditingkatkan dengan meningkatkan investasi dalam aset akan menguntungkan, yang mampu menghasilkan tingkat laba yang tinggi. Risiko tidak mampu membayar utang diukur dengan besar kecilnya modal kerja bersih (net working capital). Semakin besar modal kerja bersih, maka perusahaan semakin tidak berisiko berarti perusahaan likuid. Sebaliknya semakin kecil modal kerja bersih, maka perusahaan semakin kecil berisiko berarti perusahaan likuid.

Sedangkan rasio likuiditas adalah kemampuan mengukur likuiditas jangka pendek perusahaan dengan melihat aset lancar perusahaan relatif terhadap utang lancar (utang dalam hal ini merupakan kewajiban perusahaan).
Meskipun rasio ini tidak bicara masalah solvabilitas (kewajiban jangka panjang), dan biasanya relatif tidak penting dibandingkan rasio solvabilitas, tetapi rasio likuiditas yang buruk dalam jangka panjang juga akan memengaruhi solvabilitas perusahaan.

Aset lancar secara umum menghasilkan pengembalian hasil yang lebih rendah dibandingkan dengan aset tetap. Dari ketiga komponen aset lancar (kas, piutang, dan persediaan), persediaan biasanya dianggap merupakan asset yang paling tidak likuid. Hal ini berkaitan dengan semakin panjangnya tahap yang dilalui untuk sampai menjadi kas, yang berarti waktu yang diperlukan untuk menjadi kas semakin lama, dan juga ketidakpastian nilai persediaan. Meskipun persedian dicantumkan dalam nilai perolehan, sedangkan apabila persediaan laku, kas yang diperoleh sama dengan nilai jual yang secara umum lebih besar dibandingkan dengan nilai perolehaan.

\section{KAJIAN PUSTAKA}

Menurut Dahlan Siamat (2005: 324), dikutip dari Raflus pada tahun 1996 bahwa suatu sistem yang merupakan proses perencanaan, pengorganisasian, dan pengawasan melalui pengumpulan, proses, analisa, laporan, dan menetapkan strategi terhadap asset dan liability guna mengeliminasi risiko antara lain risiko likuiditas, risiko portepel dan risiko profitabilitas dalam menunjang pencapaian 
Jurnal Manajemen dan Bisnis Jayakarta, Volume 1, No. 2, Januari 2020

keuntungan perusahaan. Asset Liability Management merupakan sistem pengendalian aktiva dan pasiva secara terpadu yang saling berhubungan dalam usaha mencapai keuntungan perusaahaan, asset liability management merupakan kebijakan dan strategi jangka pendek dalam pencapaian rencana tahunan.

$$
\text { Dengan }
$$

demikian

manajemen perusahaan harus dikelola dengan hati-hati, aman, dan tingkat pendapatan yang wajar agar tumbuh dan mampu memenuhi kebutuhan melaksanakan pembangunan ekonomi.

Menurut Dahlan Siamat (2005: 325), tujuan utama Asset Liability Manajement (ALM) adalah untuk menstruktur portofolio sisi aktiva dan pasiva (assets liabilities) perusahaan secara konsisten, terkoodinasi, dan terpadu dalam rangka memaksimalkan keuntungan. Oleh karena itu, keputusan terhadap suatu pos aktiva dan pasiva harus dilakukan dalam konteks keseluruhan sisi neraca perusahaan.

Menurut Mamduh $M$. Hanafi (2003: 5), Laporan Keuangan suatu perusahaan pada dasarnya karena ingin mengetahui tingkat profitabilitas (keuntungan) dan tingkat risiko atau tingkat kesehatan suatu perusahaan. Laporan keuangan menurut SAK (2002: 4), laporan Keuangan merupakan bagian dari proses laporan keuangan yang lengkap, biasanya meliputi neraca, laporan laba-rugi, laporan posisi keuangan (yang dapat disajikan dalam beberapa cara seperti misalnya: laporan arus kas atau laporan arus dana), catatan, dan laporan lain serta materi penjelasan yang merupakan bagian integral dari laporan keuangan.

$$
\text { Menurut Suad Husnan }
$$
(2003: 195), bahwa Likuiditas adalah kemampuan perusahaan untuk memenuhi kewajiban finansialnya yang harus segera dipenuhi (jangka pendek). Menurut Erich A. Helfert (2003: 96), rasio yang paling umum digunakan untuk menaksir risiko hutang yang disajikan dalam neraca adalah rasio lancar.

$$
\text { Bambang Riyanto (2005: }
$$

331) menyatakan bahwa rentabilitas (profabilitas), yaitu: Rasio-rasio yang menunjukkan hasil akhir dari sejumlah kebijaksanaan dan keputusankeputusan (profit margin on sales, return on total assets, return on net worth dan lain sebagainya) atau menggambarkan kemampuan perubahan mendapatkan laba melalui semua kemampuan dan sumber yang ada seperti kegiatan penjualan, kas, modal, jumlah karyawan, jumlah cabang dan sebagainya. Menurut J. Fred Weston dan Eugene F. Brigham (1996: 57), "Rasio profitabilitas adalah memberikan ukuran tingkat efektifitas manajemen seperti ditunjukkan oleh laba yang dihasilkan dari penjualan dan dari pendapatan investasi." Adapun Freddy Rangkuti (2002: 77) mendefinisikan rasio keuntungan (profitability ratio) sebagai berikut: "Rasio keuntungan adalah ukuran untuk mengetahui seberapa jauh 
Jurnal Manajemen dan Bisnis Jayakarta, Volume 1, No. 2, Januari 2020

efektivitas manajemen dalam mengelola perusahaannya. Efektivitas manajemen meliputi kegiatan fungsional manajemen, seperti keuangan, pemasaran, sumber daya manusia, dan operasional."

Sofyan Syafri Harahap (2004: 304), "Rasio rentabilitas atau disebut juga profitabilitas menggambarkan kemampuan perusahaan mendapatkan laba melalui semua kemampuan, dan sumber yang ada seperti kegiatan penjualan, kas, modal, jumlah karyawan, jumlah cabang, dan sebagainya". Adapun menurut Agus Sartono (2001: 79), " Rasio Profitabilitas adalah rasio keuangan yang digunakan untuk mengukur kemampuan perusahaan untuk memperoleh laba dalam hubungannya dengan penjualannya, total aktiva, investasi maupun modal sendiri." Menurut Astuti (2004: 57), "Profitabilitas adalah kemampuan perusahaan menghasilkan laba. Salah satu ukuran profitabilitas yang penting adalah laba bersih. Para investor dan kreditor sangat berkepentingan dalam mengevaluasi kemampuan perusahaa menghasilkan laba saat ini maupun di masa yang akan datang." Sedangkan menurut Gitman (2006: 124), "Profitabilitas adalah suatu hubungan antara penghasilan dan biaya yang disebabkan dari penggunaan asset perusahaan (current and fixed) dalam aktiva produksi."

Untuk memberikan pengertian yang lebih jelas mengenai apa yang dimaksud dengan profitabilitas, maka dapat dilihat beberapa pendapat. Sutrisno (2003: 122), mengemukakan bahwa profitabilitas adalah kemampuan perusahaan dalam hubungannya dengan penjualan, total aktiva maupun modal sendiri.

Sedangkan menurut Saud Husnan (1993: 72), profitabilitas atau efisiensi adalah rasio untuk efisiensi penggunaan aktiva perusahaan atau mungkin juga dikaitkan dengan efisiensi penjualan yang berhasil diciptakan lebih. Menurut Bambang Riyanto (2002: 33), adalah kemampuan suatu perusahaan untuk menghasilkan laba dibandingkan dengan aktiva atau modal perusahaan yang digunakan selama periode tertentu dan dinyatakan dengan presentase.

Menurut Sugiyarso (2005: 325-327), "Analisis rasio dapat memberikan informasi yang berguna tentang operasi dan keuangan perusahaan, namun rasio ini memiliki keterbatasan yang waspadai dan pertimbangkan."

Definisi pelaporan kinerja menurut Welsch, Hilton, Gordon (1998: 276), dalam bukunya Perencanaan dan Pengendalian Laba "Pelaporan kinerja merupakan suatu bagian penting dari prosedur pengendalian yang dilakukan manajemen yang dapat mendorong para manajer bertindak sesuai harapan mereka".

Berdasarkan penjelasan diatas, maka peneliti membuat kerangka pemikiran dengan menggunakan dua varibel bebas yaitu likuiditas dan profitabilitas 
Jurnal Manajemen dan Bisnis Jayakarta, Volume 1, No. 2, Januari 2020

dan satu variabel terkait, yaitu asset liability management penelitian sebagai berikut:

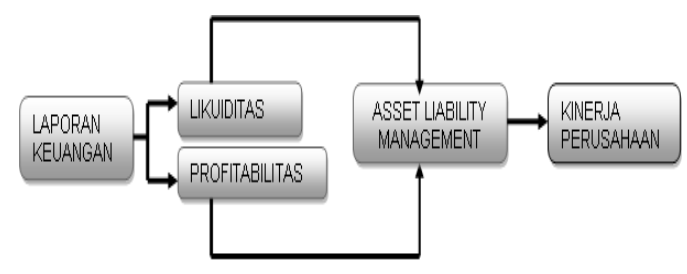

Dalam menjaga asset liability manajement suatu perusahaan diperlukan analisa rasio keuangan yang tepat. Rasio yang biasa digunakan suatu perusahaan adalah rasio likuiditas dan rasio profitabilitas kedua rasio tersebut berfungsi agar asset lialibity manajemen dapat dipertahankan dengan baik dalam suatu perusahaan. Rasio likuiditas digunakan untuk mengukur kemampuan perusahaan memenuhi utang jangka pendeknya dengan menggunakan aktiva lancar. Sedangkan rasio profitabilitas digunakan untuk mengetahui tingkat kemampu daarian perusahaan menghasilkan laba dari investasi yang dilakukan.

\section{METODE}

Dalam penelitian ini Rasio Likuiditas diukur dengan rasio lancar dan rasio Quick. Sedangkan Rasio Profitabilitas diukur dengan ratio Return on Asset (ROA), Return on Equtiy (ROE) dan Net profit margin. Sedangkan Asset Liability Management adalah sistem pengendalian aktiva dan pasiva secara terpadu yang saling berhubungan dalam usaha mencapai keuntungan perusahaan asset dan liability management merupakan kebijakan dan strategi jangka pendek dalam pencapaian rencana tahunan. Asset Liability Manajement (ALM) adalah untuk menstruktur portofolio sisi aktiva dan pasiva (asset liabilities) perusahaan secara konsisten, terkoodinasi, dan terpadu dalam rangka memaksimalkan keuntungan. Oleh karena itu, keputusan terhadap suatu pos aktiva dan pasiva harus dilakukan dalam konteks keseluruhan sisi neraca perusahaan.

Jenis penelitian yang digunakan adalah penelitian kepusatakaan (library research). Pencarian data sekunder dilakukan melalui pemahaman beberapa literature yang diperoleh dari kepustakaan yang berhubungan dengan objek penelitian yang dilakukan dan dapat dipakai sebagai landasan teori sebagai sejarah perusahaan, struktur organisasi perusahaan, struktur tata kelola perusahaan, gambaran umum mengenai aktivitas perusahaan, laporan keuangan, neraca, laporan laba rugi perusahaan, serta data lainnya

Data dalam penelitian ini diperoleh dari laporan keuangan konsolidasi per tahun yang telah diterbitkan oleh PT Pelita Air Service dan melalui situs resmi milik PT Pelita Air Service. Data yang dilakukan berdasarkan dokumentasi yang dimiliki oleh perusahaan tersebut adalah berupa struktur organisasi, neraca perusahaan, laporan laba-rugi serta data penjualan. 
Jurnal Manajemen dan Bisnis Jayakarta, Volume 1, No. 2, Januari 2020

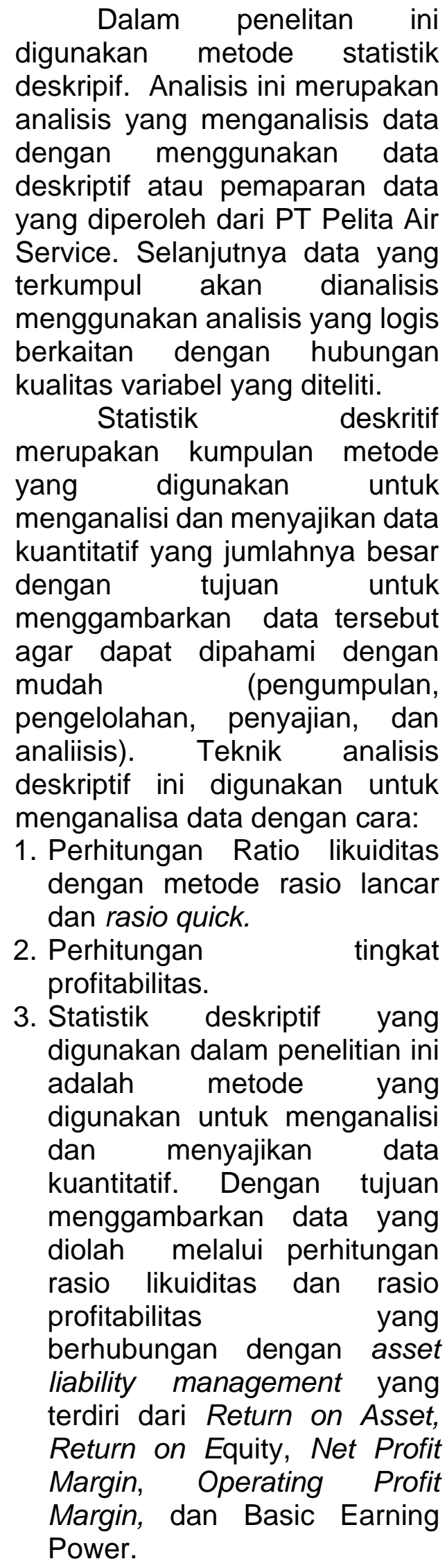

Penelitian dilakukan di perusahaan jasa penerbangan yang berlokasi di jalan Abdul Muis nomor 52-56A Jakarta Pusat. Perusahaan ini berlogo kuda laut yang bernama PT Pelita Air Service. PT Pelita Air Sevice bergerak dibidang jasa penerbangan khususnya penerbangan charter flight. PT Pelita Air Service merupakan salah satu dari anak perusahaan Pertamina Persero. Kantor pusatnya berlokasi di jalan Abdul Muis nomor 52-56A Jakarta Pusat, untuk kantor cabang dan opersionalnya berada di Halim Perdana Kusuma, Surabaya, Ujung Pandang, Sorong, Balikpapan, Dumai, Pekanbaru, dan Singapore.

\section{HASIL DAN PEMBAHASAN}

Untuk menganalisis tingkat likuiditas PT Pelita Air Service selama tiga tahun terakhir mulai dari tahun 2009-2011 metode perhitungan yang digunakan adalah current rasio, quick ratio dan cash ratio.

Sebelum melakukan pembahasan lebih lanjut disajikan ringkasan neraca perbandingan PT Pelita Air Service dari tahun 2009 sampai 2011 yang mencakup total aset dan total kewajiban /utang. Komposisi aktiva (asset) perusahaan serta komposisi utang (liabilities) dan modal (equity) yang pembiayanya disajikan dalam suatu laporan yang dikenal dengan nama Neraca (Balance Sheet). Didalam neraca pada umumnya komponen aktiva (asset) merupakan sumber ekonomis perusahaan yang juga meliputi biaya-biaya yang telah 
Jurnal Manajemen dan Bisnis Jayakarta, Volume 1, No. 2, Januari 2020

terjadi yang diakui berdasarkan prinsip akutansi yang berlaku.

Setelah data tersebut terkumpul, dilakukan analisis terhadap rasio likuiditas dan rasio profitabilitas hubungannya dengan Asset Liability Management pada PT Pelita Air Service yang menunjukkan seberapa besar kemampuan perusahaan untuk memenuhi kewajiban jangka pendeknya (utang lancar) pada saat jatuh tempo.

Tabel 1. Aset Lancar dengan Utang Lancar

Pada PT Pelita Air Service (Rupiah 000)

\begin{tabular}{|c|c|c|c|}
\hline \multirow{2}{*}{$\begin{array}{c}\text { Uraia } \\
\mathbf{n}\end{array}$} & \multicolumn{3}{|c|}{ Tahun } \\
\hline & 2009 & 2010 & 2011 \\
\hline $\begin{array}{l}\text { Aset } \\
\text { Lanca } \\
r\end{array}$ & $\begin{array}{l}220.519 .07 \\
9\end{array}$ & $\begin{array}{l}209.717 .21 \\
6\end{array}$ & $\begin{array}{l}317.535 .36 \\
9\end{array}$ \\
\hline $\begin{array}{l}\text { Utang } \\
\text { Lanca } \\
r\end{array}$ & $\begin{array}{l}334.978 .40 \\
7\end{array}$ & $\begin{array}{l}290.485 .13 \\
5\end{array}$ & $\begin{array}{l}303.682 .98 \\
0\end{array}$ \\
\hline
\end{tabular}

Sumber : Olah data PT Pelita Air Service

Maka diperoleh perhitungan rasio lancar sebagai berikut:

$$
\begin{gathered}
\text { Tahun } 2009=\frac{220,519,079}{334,978,407} \times 100 \% \\
=0,6583 \\
=66 \%
\end{gathered}
$$

Tahun $2011=\frac{317,535,369}{303,682,980} \times 100 \%$ $=104,561$

\begin{tabular}{|c|c|c|c|}
\hline \multirow{2}{*}{$\begin{array}{l}\text { Urai } \\
\text { an }\end{array}$} & \multicolumn{3}{|c|}{ Tahun } \\
\hline & 2009 & 2010 & 2011 \\
\hline $\begin{array}{l}\text { Aset } \\
\text { Lancar }\end{array}$ & $\begin{array}{l}220.519 .0 \\
79\end{array}$ & $\begin{array}{l}209.717 .2 \\
16\end{array}$ & $\begin{array}{l}317.535 .3 \\
69\end{array}$ \\
\hline $\begin{array}{l}\text { Persediaa } \\
\mathrm{n}\end{array}$ & $\begin{array}{l}19.949 .89 \\
9\end{array}$ & $\begin{array}{l}14.220 .24 \\
2\end{array}$ & $\begin{array}{l}14.580 .55 \\
8\end{array}$ \\
\hline $\begin{array}{l}\text { Utang } \\
\text { Lancar }\end{array}$ & $\begin{array}{l}334.978 .4 \\
07\end{array}$ & $\begin{array}{l}290.485 .1 \\
35\end{array}$ & $\begin{array}{l}303.682 .9 \\
80\end{array}$ \\
\hline
\end{tabular}$$
=105 \%
$$

Tabel 2. Aset lancar, Persedian dan Utang lancar Pada PT Pelita Air Service (Rupiah 000)
Sumber : Olah data PT Pelita Air Service

Maka diperoleh perhitungan rasio quick sebagai berikut:

$$
\begin{aligned}
\text { Tahun } 2009 & =\frac{200,569,180}{334,978,407} \times 100 \% \\
& =59,8752 \\
& =60 \%
\end{aligned}
$$

Tahun $2010=\frac{195,496,974}{290,485,135} \times 100 \%$

$$
=67,3001
$$$$
=67 \%
$$

Tahun $2011=\frac{302,954,811}{303,682,980} \times 100 \%$

$$
\begin{aligned}
& =99,760 \\
& =99 \%
\end{aligned}
$$

Dari hasil analisis di atas dapat dilihat quick rasio perusahaan

\section{Tabel 3. Kas dan setara kas dan Utang Lancar \\ Pada PT Pelita Air Service} (Rupiah 000)

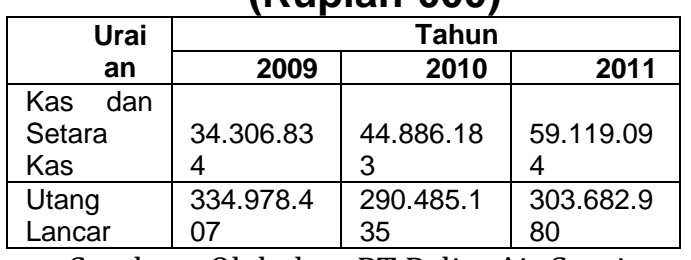

Sumber : Olah data PT Pelita Air Service

Maka diperoleh perhitungan rasio kas sebagai berikut

$$
\begin{aligned}
\text { Tahun } 2009 & =\frac{34,306,834}{334,978,407} \times 100 \% \\
& =0,10 \\
& =10 \%
\end{aligned}
$$


Jurnal Manajemen dan Bisnis Jayakarta, Volume 1, No. 2, Januari 2020

$$
\begin{aligned}
\text { Tahun } 2010 & =\frac{44,886,183}{290,485,135} \times 100 \% \\
& =0,15 \\
& =15 \% \\
\text { Tahun } 2011 & =\frac{59,119,094}{303,682,980} \times 100 \% \\
& =0,19 \\
& =19 \%
\end{aligned}
$$

\section{Tabel 4. Rasio Likuiditas \\ PT Pelita Air Service (dalam \%)}

\begin{tabular}{|c|r|r|r|}
\hline \multirow{2}{*}{ Tahun } & \multicolumn{3}{|c|}{ Rasio Likuiditas } \\
\cline { 2 - 4 } & CR & QR & \multicolumn{1}{c|}{ CAR } \\
\hline 2009 & 66 & 60 & 10 \\
\hline 2010 & 72 & 67 & 15 \\
\hline 2011 & 105 & 99 & 19 \\
\hline
\end{tabular}

Sumber : Olah data PT Pelita Air Service

Berdasarkan table diatas dapat diketahui bahwa tingkat likuiditas perusahaan dengan menghitung current ratio sudah cukup baik walaupun dari tahun ke tahun mengalami penurunan tetap sudah mendekati standar industri yaitu 1:2 atau berada diatas $100 \%$. Dan jika dilihat dari cash rasionya kemampuan perusahaan untuk memenuhi kewajiban lancar dengan kas dan setara kas/kas bank rendah.

Untuk kelangsungan suatu perusahaan ditekankan pada profitabilitas, karena tanpa adanya keuntungan akan sulit untuk menarik modal dari luar. Para kreditur, perusahaan dan teruma pihak manajemen perusahaan berusaha meningkatkan keuntungan ini, karena pada umumnya tujuan pokok suatu perusahaan dalam melaksanakan kegiatannya yaitu mengoptimalkan laba perusahaan dan menjaga kontinuitas perusahaan.

\section{Tabel 4. Rasio Profitabilitas PT Pelita Air Service Periode 31 Des 2009-2011}

\begin{tabular}{|c|c|c|r|c|}
\hline \multirow{2}{*}{$\begin{array}{c}\text { Tahu } \\
\mathbf{n}\end{array}$} & \multicolumn{4}{|c|}{ Rasio Profitabilitas } \\
\cline { 2 - 5 } & NPM & AT & $\begin{array}{r}\mathbf{R} \\
\mathbf{O} \\
\mathbf{I}\end{array}$ & $\begin{array}{c}\text { RO } \\
\mathbf{E}\end{array}$ \\
\hline 2009 & $7,50 \%$ & 80 Kali & $60 \%$ & $19,83 \%$ \\
\hline 2010 & $1,93 \%$ & 80 Kali & $1,56 \%$ & $1,93 \%$ \\
\hline 2011 & $3,08 \%$ & $\begin{array}{c}85 \\
\text { Kali }\end{array}$ & $2,63 \%$ & $6,94 \%$ \\
\hline
\end{tabular}

Berdasarkan tabel di atas dapat diketahui bahwa tingkat profitabilitas yang dicapai dengan menggunakan Net Profit Margin (NPM) perusahaan, apabila dilihat perkembangannya dari tahun 2009-2011 hasilnya berfluktuasi, pada tingkat profit (laba). Asset turnover (AT) perusahaan, apabila dilihat perkembanganya dari tahun 2009-2011 hasilnya dinyatakan berfluktuasi, walapun penurunannya sedikit, perusahaan mendapatkan keuntungan. Return on Invesment (ROI) atau Retrun on Asset (ROA) dan Return on Equity (ROE) dari tahun 2009 mengalami peningkatan dan pada 2010 mengalami penurunan dan tahun 2011 menunjukkan hasil yang dinyatakan dengan presntase meningkat. Hasil ini menunjukan tingkat ROE berfluktuasi, sehingga dapat dikatakan bahwa hasil analisis rasio likuiditas dan rasio profitabilitas selam tiga tahun dapat terbukti cukup efesien jika dilihat dari hasil analisis dari perusahaan tersebut.

Tabel 5. Analisis Perusahaan dengan Rasio 
Jurnal Manajemen dan Bisnis Jayakarta, Volume 1, No. 2, Januari 2020

Likuiditas dan Rasio

Profitabilitas

PT Pelita Air Service

(Dalam \%)

\begin{tabular}{|c|c|c|c|c|}
\hline \multirow{2}{*}{ No. } & \multirow{2}{*}{ Uraian } & \multicolumn{3}{|c|}{ Tahun } \\
\hline & & 2009 & 2010 & 2011 \\
\hline \multirow[t]{4}{*}{ I. } & $\begin{array}{l}\text { Rasio } \\
\text { Likuiditas }\end{array}$ & & & \\
\hline & Current Ratio & 66 & 72 & 105 \\
\hline & Quick Ratio & 60 & 67 & 99 \\
\hline & Cash Ratio & 10 & 16 & 19 \\
\hline \multirow[t]{8}{*}{ II. } & $\begin{array}{l}\text { Rasio } \\
\text { Profitabilitas }\end{array}$ & & & \\
\hline & $\begin{array}{ll}\text { Net } & \text { Profit } \\
\text { Margin } & \end{array}$ & 7,50 & 1,93 & 3,80 \\
\hline & Asset Turnover & $\begin{array}{c}80 \\
\text { Kali }\end{array}$ & $\begin{array}{c}80 \\
\text { Kali }\end{array}$ & $\begin{array}{c}85 \\
\text { Kali }\end{array}$ \\
\hline & ROA/ROI & 60 & 1,56 & 2,63 \\
\hline & ROE & 19,83 & 1,93 & 6,94 \\
\hline & $\begin{array}{l}\text { Gross } \\
\text { Margin }\end{array}$ & 26 & 23 & 24 \\
\hline & $\begin{array}{l}\text { Operating Profit } \\
\text { Margin }\end{array}$ & 4.99 & $-2,27$ & 3,10 \\
\hline & $\begin{array}{ll}\text { Basic } & \text { Profit } \\
\text { Margin } & \end{array}$ & 9,83 & 2,98 & 4,91 \\
\hline
\end{tabular}

Analisis Kinerja PT PELITA AIR SERVICE Hubungannya dengan Asset Liability Management

Pada umumnya angkutan udara, laut, maupun udara memainkan peranan penting di dalam kegiatan industri. Khususnya angkutan udara sangatlah menonjol dalam fungsinya sebagai penunjang kegiatan industri minyak karena faktor kecepatan dan ketepatannya.

Salah satu sifat pesawat udara, mampu bergerak tiga dimensi dan hampir tidak dirintangi oleh rintangan geografis seperti halnya di darat dan di laut. Kecepatan pesawat terbang yang paling lamban sekalipun, masih lebih cepat daripada angkutan lainnya.

Faktor yang paling berhasil dihemat sangat menguntungkan dalam Industri perminyakan. Apalagi bila dilihat hubungannya dengan .Asset Liability Management dengan melihat dua fungsi rasio yang bersangkutan didalamnya yaitu rasio likuiditas dan rasio profitabilitas. Pada sistem ini merupakan suatu perencanaan, pengeorganisasian dan pengawasan melalui pengumpulan, proses, analisis laporan, dan menetapkan strategi asset dan liability guna mengeliminasi risiko. Untuk itu kemapuan perusahaan melaksanakan fungsi secara efisien sesuai kebutuhan dan sasaran perekonomian, termasuk peranannya dalam mendorong pertumbuhan dan pembanguan ekonomi sangat ditentukan oleh efisiensi dari manajemen perusahaan itu sendiri.

Asset Liability Management merupakan suatu sistem pengendalian aktiva dan pasiva secara terpadu yang saling berhubungan dalam usaha mencapai keuntungan perusahaan dengan kebijakan dan strategi jangka pendek dalam pencapaian rencana tahunan. Asset Liability Management berfungsi untuk meminimalisir berbagai risiko menyangkut asset dan liability guna memaksimumkan keuntungan dan hasil yang dibagikan kepada para pemegang saham dalam jangka 
Jurnal Manajemen dan Bisnis Jayakarta, Volume 1, No. 2, Januari 2020

panjang dengan memperhatikan kebutuhan likuiditas.

Dalam rasio likuiditas maka yang menjadi tolak ukur Asset (Aktiva) salah satunya adalah Current ratio (Rasio Lancar) merupakan ukuran yang paling umum digunakan untuk mengetahui kesanggupan memenuhi kewajiban jangka pendek. Dari hasil analisis laporan keuangan maka PT Pelita Air Service maka tahun 2009 Current ratio perusahaan meningkat dari hasil tahun sebelumnya 2008, karena adanya pengurangan piutang usaha pada pihak ketiga berarti, piutang tidak tertagih semakin berkurang. Hal ini menunjukkan tahun 2009 risiko sebesar $66 \%$, sedangkan tahun $201072 \%$, dan 2011 sebesar $105 \%$ yang diperoleh dengan perbandingan aktiva lancar dengan utang lancar. Hal ini berarti setiap Rp1,utang lancar dapat dijamin oleh aktiva lancar pada tahun 2009 sebesar $\mathrm{Rp}$ 66,- , sedangkan 2010 Rp72,- dan 2011 Rp105,-.

Laporan Keuangan suatu perusahaan pada dasarnya karena ingin mengetahui tingkat profitabilitas (keuntungan) dan tingkat risiko atau tingkat kesehatan suatu perusahaan.

Dalam proses ini laporan keuangan diidentifikasikan berbagai transaksi yang merupakan kegiatan ekonomi perusahaan, yang dilakukan melalui pengukuran, pencatatan, penggolongan, dan pengikhtisar transaksi yang bersifat keuangan, sehingga hanya informasi yang relevan dan saling berhubungan satu dengan yang lainnya yang mampu memberikan gambaran secara layak tentang keadaan keuangan serta hasil perusahaan dalam periode yang akan digabungkan dan disajikan dalam bentuklaporan keuangan.

$$
\text { Laporan keuangan }
$$

merupakan pertanggungjawaban keuangan pimpinan atas perusahaan yang telah dipercayakan kepadanya.Kondisi keuangan dan hasil-hasil operasi perusahaan tercemin dalam laporan keuanga perusahaan, pada hakekatnya merupakan hasil akhir dari kegiatan perusahaan yang dapat menggambarkan performa atau kinerja keuangan dari perusahaan yang bersangkutan.

Dalam rasio profitabilitas maka yang menjadi tolak ukur keuntungan (profit) pada tingkat penjualan, asset, dan modal saham yang tertentu. Analisis profitabilitas, yang didasarkan pada laporan keuangan, salah satunya adalah Net Profit Margin (NPM) merupakan hubungan antara laba bersih setelah pajak dengan penjualan menunjukkan tingkat keuntungan bersih yang diperoleh dari bisnis.

Dari hasil analisisi laporan keuangan maka PT Pelita Air Service maka tahun 2009 Net Profit Margin sebesar 7,50 \%. Hal ini berarti setiap Rp1,menghasilkan keuntungan neto sebesar $R p$ 750,-. sedangkan, tahun 2010 terjadi penurunan dari 7,50\% tahun 2009 menjadi $1,93 \%$ tahun 2010 . Hal ini berarti setiap Rp1,- penjualan menghasilkan keuntungan neto sebesar Rp193,-. Pada tahun 
Jurnal Manajemen dan Bisnis Jayakarta, Volume 1, No. 2, Januari 2020

2011 mengalami peningkat dari tahun 2010 sebesar 7,50 \% berubah menjadi 3,08 \% tahun 2011. Hal ini berarti bahwa setiap Rp1-, penjualan akan mengahasilkan keuntungan neto sebesar Rp308-,. Berdasarkan analisis Net Profit Margin, maka dapat diperoleh gambaran tentang seberapa besar keuntungan yang diperoleh perusahaan. Dengan mengetahui tingkat Net Profit Margin yang dicapai perusahaan selama tiga tahun terakhir. Hal ini menunjukkan perbandingan antara laba bersih sesudah pajak dengan penjualan bersih, mengalami hasil yang berfluktuasi maka rasio dapat dikatakan cukup efisien dalam mengendalikan biaya dan beban berkaitan dengan penjualan. Semakin efisien (profit) keuntungan suatu perusahaan dalam hal pengeluaran biayabiaya perusahaan maka semakin meningkat keuntungan yang akan diperoleh perusahaan pada tepatnya perusahaan yang sedang tumbuh dan berkembang.

\section{KESIMPULAN}

Berdasarkan hasil penelitian dan pembahasan yang telah dikemukakan maka menghasilkan kesimpulan sebagai berikut:

1. Dalam prosedur pada suatu laporan keuangan perusahaan yang hubungannya dengan Asset Liability Management, terdapat sebuah langkah peranan sistem pengendalian aktiva dan pasiva secara terpadu saling berhubungan dalam usaha mengatasi permasalahan utang perusahaan, sistem ini berperan memaksimalkan laba, meminimalkan risiko dan menjamin tersediaanya likuiditas yang cukup, agar potensi resiko yang dihadapi perusahaan dapat terkontrol. Fokus dan tujuan manajemen Asset dan Liabilitas adalah mengoptimalkan pendapatan dan menjaga risiko tidak melapaui batas yang dapat ditoleransi, disamping itu juga memaksimalkan harga pasar dari ekuitas perusahaan. Manajemen yang bekerja di dalamnya juga memiliki tugas sebagai sistem yang membantu seorang manajer keuangan untuk merencanakan, mengelola, mengevaluasi, melalui pengumpulan proses, analisa, laporan dan menempatkan startegi yang terdapat asset (aktiva) dan liability (utang) guna mengeliminasi risiko likuiditas yang mengukur kemampuan perusahaan dalam memenuhi kewajiban financial yang segera dipenuhi. Sedangkan Liabilitynya (kewajiban) dapat dilihat dengan kebijakan dan strategi jangka pendek pada sisi aktiva dan pasiva perusahaan dalam mengelolah utang perusahaannya. Asset liabilities yang secara konsiten, terkoordinasi dan terpadu dalam rangka memaksimalkan keuntungan (profitabiilitas), menjaga likuiditas yang memadai, dan memelihara sumber pendanaan.

2. Berdasarkan hasil analisis rasio keuangan terhadap laporan keuangan perusahaan menunjukkan bahwa PT Pelita Air Service masih likuid, sehingga asset lancar yang dimiliki dapat menjamin untuk melunasi utang-utang jangka pendeknya. Tetapi utang jangka 
Jurnal Manajemen dan Bisnis Jayakarta, Volume 1, No. 2, Januari 2020

pendek perusahaan yang harus segera jatuh tempo lebih besar dari pada utang jangka panjagnya. Kemampuan perusahaan juga masih sangat mencetak laba, hal itu dapat dilihat ketika tahun 2011 mengalami penurunan. Sehingga profitabilitas selama tiga tahun dapat terbukti kurang efesien jika dilihat dari hasil analisis dari perusahaan tersebut. Karena kurang memanfaatkan aktiva perusahaa, sehingga perusahaan perlu meningkatkan profit margin dengan menekankan biaya-biaya operasi yang dianggap kurang efektif. Dari analisis rasio likuiditas dan keuangan dikatakan bahwa hasil selama tiga tahun dapat terbukti efisien jika dilihat pada analisis dari perusahaankan tersebut.

\section{REFERENSI}

Astuti. 2004. Manajemen Keuangan Perusahaan. Jakarta: Ghalia Indonesia.

Gitman, L.J. 2006. Principle of Managerial Finance. Edisi Kesebelas. Boston: Wesley.

Hanafi, Mamduh M. 2003. Teori Aplikasi Manajemen Keuangan. Edisi Keempat. Yogyakarta: BPFE.

Harap, Sofyan Syafri. 2004. Analisis Kritis atas Laporan Keuangan. Edisi Pertama. Cetakan Keempat. Jakarta: Financial Reports.

Helfert, Eric A. 2003. Teknik Keuangan Praktis Menggunakan Pengukuran Kinerja Perusahaan. Jakarta: Erlangga.

Husnan, Suad. 2002. Dasar-Dasar Manajemen Keuangan Pembelanjaan Perusahaan. Edisi Keempat.Yogyakarta: Liberty.
Ikatan Akuntan Indonesia. 2002. Standar Akuntansi Keuangan.Jakarta: IAI.

Rangkuti, Freddy. 2002. Teknik Mengukur dan Strategi Meningkatkan Kepuasan Pelanggan Plus Analisis Laporan Keuangan. Jakarta: PT Gramedia Pustaka Utama.

Riyanto, Bambang. 2005. Dasar-Dasar Pembelanjaan Perusahaan. Edisi Keempat. Cetakan Ketujuh. Yogyakarta: BPFE.

Sartono, Agus. 2001. Manajemen Keuangan Teori dan Aplikasi. Edisi Keempat. Cetakan Pertama. Yogyakarta: BPFE.

Siamat, Dahlan. 2005. Manajemen Lembaga Keuangan Kebijakan Moneter dan Perbankan. Edisi Kelima. Jakarta: Fakultas Ekonomi Universitas Indonesia.

Sugiyarso. 2005. Pemahaman Laporan Keuangan Pengelolaan Aktiva, Kewajiban dan Modal serta Pengukuran Kinerja Perusahaan. Yogyakarta: Media Pressindo.

Sutrisno, 2003, Manajemen Keuangan, Penerbit Ekonisia Fakultas Yogyakarta: Ekonisia Fakultas Ekonomi UII.

Welsh, Hilton and Gordon. 1998. Perencanaan dan Pengendalian Laba. Edisi Keempat. Jakarta: Erlangga.

Weston, J. fred and Eugene F. Bringhamk. 1996. Dasar-dasar Manajemen Keuangan. Edisi Kesembilan. Jakarta: Erlangga. 